Kumawula, Vol. 2, No.2, Agustus 2019, Hal 183 - 191 DOI:http://10.24198/kumawula.v1i3.24406

ISSN 2620-844X (online)

Tersedia online di http://jurnal.unpad.ac.id/kumawula/index

\title{
PENINGKATAN PERAN AKTIF APARATUR DESA DAN PARTISIPASI MASYARAKAT DALAM UPAYA PELESTARIAN LINGKUNGAN MELALUI PELATIHAN PEMBUATAN ECOBRICKS
}

\author{
Dini Sri Istiningdias ${ }^{1}$, Dewi Noor Azijah², Gili Argenti ${ }^{3}$ \\ 1,2,3 Program Studi Ilmu Pemerintahan, Universitas Singaperbangsa Karawang \\ 1'dini.sri@staff.unsika.ac.id, ${ }^{2}$ dewi.noor1992@gmail.com,, ${ }^{3}$ gili.argenti@fisip.unsika.ac.id
}

\begin{abstract}
ABSTRAK
Kegiatan pengabdian ini mengacu kepada upaya untuk dapat mengurangi dampak dari sampah plastik yang tidak diolah dan mempengaruhi kualitas lingkungan di Desa Siluman Kabupaten Subang. Permasalahan sampah merupakan permasalahan krusial seperti sampah bermaterial plastik yang sangat sukar untuk terurai. Oleh sebab itu diperlukan upaya sinergis dari berbagai pihak baik lembaga pemerintah maupun masyarakat umum untuk dapat menuntaskan permasalahan sampah terutama yang disebabkan oleh sampah plastik. Sehingga dampak negatif dari sampah plastik tersebut dapat dikurangi bahkan dihentikan.

Tujuan dari kegiatan pengabdian ini adalah untuk Menumbuhkan kesadaran tentang betapa pentingnya menjaga lingkungan dari penumpukan sampah terutama yang berbahan material plastik; Mendorong keterlibatan aparatur desa serta masyarakat untuk bersinergi dalam menjaga lingkungan, dan; Memotivasi masyarakat untuk terus melakukan inovasi dalam rangka mengurangi dampak sampah terutama yang berbahan material plastik.

Seluruh kegiatan Pengabdian ini diselenggarakan selama 6 bulan, di Karawang. Melalui beberapa kegiatan yang berkesinambungan yaitu: (a). Identifikasi Permasalahan sampah melalui FGD, (b). Sosialisasi program Ecobriks,(c) Pelaksanaan simulasi pembuatan produk hasil Ecobriks.
\end{abstract}

Kata Kunci: Sampah, ecobricks, pelestarian, lingkungan

\section{THE AWARENESS ENHANCEMENT OF VILLAGE GOVERNMENT AND SOCIETY PARTICIPATION IN ENVIRONMENTAL PRESERVATION THROUGH ECOBRICKS TRAINING}

\begin{abstract}
This article refers to efforts for reducing the impact of untreated plastic waste that affects the quality of the environment in Siluman Village, Subang Regency. The problem regarding rubbish is a crucial problem, especially with plastic material waste which is very difficult to decompose. Therefore, we need a synergistic effort from various parties, incliuding government agencies and the general public to be able to solve the rubbish problem, especially those caused by plastic waste. So that the negative impact of plastic waste can be reduced or even stopped.

The purpose of this community service activity is to raise awareness about how important it is to protect the environment from the accumulation of rubbish, especially those made from plastic material; Encourage the involvement of village officials and the community to work together in protecting the environment, and; Motivate the community to continue the innovation in order to reduce the impact of rubbish, especially those made from plastic materials.
\end{abstract}


The entire Community Service activity was around 6 months. Through several continuous activities, namely: (a). Rubbish problem identification through FGD, (b). Socialization of the Ecobrics program, (c) Implementation of the simulation of making Ecobriks products.

Keywords: Rubbish, Ecobricks, Preservation, Environment

\section{PENDAHULUAN}

Permasalahan sampah adalah suatu persoalan yang tak kunjung selesai. Semakin meningkatnya jumlah penduduk di Indonesia yang mengakibatkan semakin tingginya pula tingkat konsumsi terhadap produk-produk penunjang aktivitas sehari-hari menjadi suatu hal yang tak dapat dihindari. Terutama produk-produk yang dibuat menggunakan material plastik, di mana material itu merupakan bahan yang sukar terurai. Dari hasil penelitian yang dipublikasikan pada Jurnal Science (www.sciencemag.org) pada tanggal 12 Februari 2015, menunjukkan bahwa Indonesia berada pada posisi ke-2 dari 5 besar penyumbang sampah plastik terbesar ke lautan dengan urutan Tiongkok, Indonesia, Filipina, Vietnam dan Srilanka. Hal tersebut tentu saja bukan merupakan sesuatu yang membanggakan, karena dari data tersebut membuktikan bahwa belum adanya pengelolaan sampah yang baik di Indonesia, yang menyebabkan laut ikut terdampak oleh adanya sampah plastik.

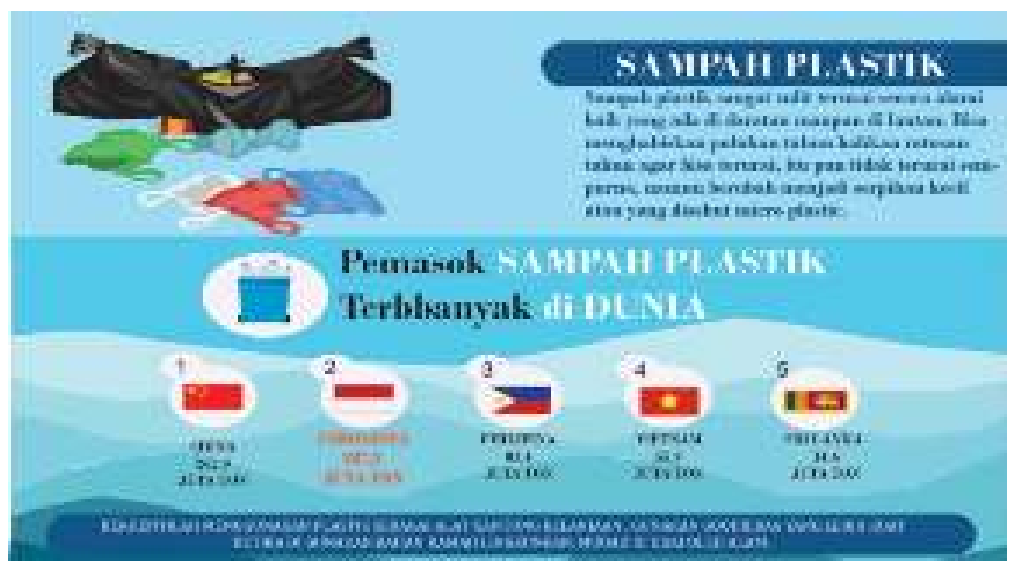

Gambar 1. Peringkat pemasok sampah plastik terbanyak di dunia

Dilansir dari media CNN, bahwa persoalan pengelolaan sampah memang masih menjadi pekerjaan rumah yang perlu diperhatikan oleh Indonesia. Berdasarkan hasil penelitian dari Sustainable Waste Indonesia (SWI) terungkap bahwa ada sebanyak 24\% sampah di Indonesia masih belum mampu terkelola dengan baik. Di mana hal tersebut dapat dijadikan asumsi bahwa dari sebanyak 65 juta ton sampah yang diproduksi di Indonesia setiap harinya, dengan proporsi 7 persen sampah didaur ulang dan 69\% sampah berakhir di Tempat Pembuangan Akhir (TPA), masih ada kurang lebih 15 juta ton dari sampah tersebut yang mengancam ekosistem dan lingkungan yang diakibatkan tidak adanya upaya untuk menangani 
sampah-sampah tersebut. Dari hasil laporan SWI tersebut juga diketahui bahwa jenis sampah yang paling banyak dihasilkan ialah sampah organik sebanyak $60 \%$, sampah plastik 14\%, diikuti sampah kertas (9\%), metal (4,3\%), kaca, kayu dan bahan lainnya $(12,7 \%)$.

Direktur SWI, Dini Trisyanti mengatakan bahwa "Ada 1.3 juta sampah plastik per/tahun yang tidak dikelola". Di mana jumlah tersebut dinilai masih sangat banyak serta kita ketahui bersama bahwa sampah plastik termasuk dalam kategori material yang sukar terurai. Jika sampah bermaterial plastik tersebut tidak dikelola di TPA atau dilakukan proses daur ulang (Recycling) maka sampah tersebut akan merusak ekosistem. Hal ini disebabkan karena sampah plastik tersebut apabila tidak dikelola maka biasanya akan tertimbun di dalam tanah atau ikut mengalir ke lautan.

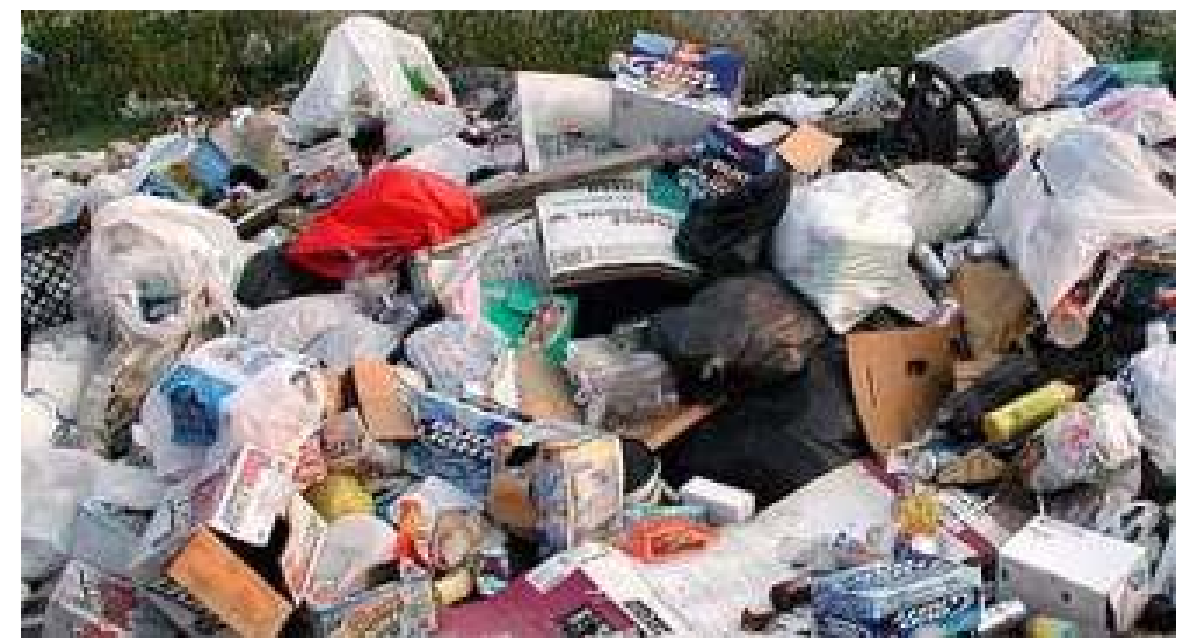

Gambar 2. Kondisi tumpukkan sampah plastik yang tidak terkelola

Direktur SWI itu pun mengatakan bahwa tingginya angka sampah yang tidak terkelola dapat dipengaruhi oleh beberapa aspek. Pertama, ialah ketiadaan sistem yang memadai untuk proses pengumpulan sampah. Proses pengumpulan ini biasanya dilakukan para pemulung di jalanan, atau petugas kebersihan yang mengangkut sampah-sampah dari tiap rumah tangga menggunakan truk. Proses pengumpulan sampah ini dinilai belum optimal, karena belum bisa menjangkau semua sampah. "Kita ada 400 kota kabupaten di Indonesia, nggak semuanya seperti di Jakarta, ada truk sampah," ucap Dini.

Hal kedua yang patut jadi perhatian ialah perilaku dan kebiasaan masyarakat Indonesia itu sendiri, yang sering membuang sampah langsung ke sungai atau ke alam. Sampah-sampah ini tidak masuk ke dalam proses pengumpulan yang dilakukan pemulung dan petugas kebersihan, hingga akhirnya mengotori ekosistem. Meskipun di lain sisi, Dini juga menganggap masyarakat tidak bisa sepenuhnya disalahkan, karena Indonesia masih punya banyak hambatan 
infrastruktur pelayanan sampah. Masyarakat sering membuang sampah sembarangan karena tidak adanya tempat pengumpulan sampah atau TPA di sekitar tempat tinggalnya, sehingga mereka bingung harus membuang sampah ke mana. Aspek ketiga yang menyebabkan masih ada sampah yang tidak terkelola ialah ketiadaan Infrastruktur dan optimalisasi pelayanan sampah yang kerap terkendala karena anggaran yang terbatas. Serta peningkatan pelayanan sampah juga masih belum dijadikan prioritas oleh pemerintah.

Ketiga aspek penyebab tidak terkelolanya sampah juga turut melanda salah satu desa di Kabupaten Subang, yaitu Desa Siluman. Sebagai salah satu desa di Kabupaten Subang yang memiliki jarak tempuh cukup jauh dari ibukota kabupaten, yakni sekitar $51 \mathrm{Km}$ atau sekitar 1 $1 / 2$ jam perjalanan, memiliki problem mengenai pengelolaan sampah. Di mana di desa tersebut tidak memiliki TPS (Tempat Pembuangan Sampah) karena tempat pembuangan sampah terdekat ada di belakang pasar kecamatan yang berjarak $3 \mathrm{KM}$ dari desa, dan tempat pembuangan sampah tersebut pun, yang sebenarnya juga bukan TPS resmi, berada di areal persawahan di mana ini pun menyebabkan permasalahan atau turut berdampak pada kualitas persawahan yang disebabkan cairan dari sampah mengalir dan menyatu dengan persawahan.

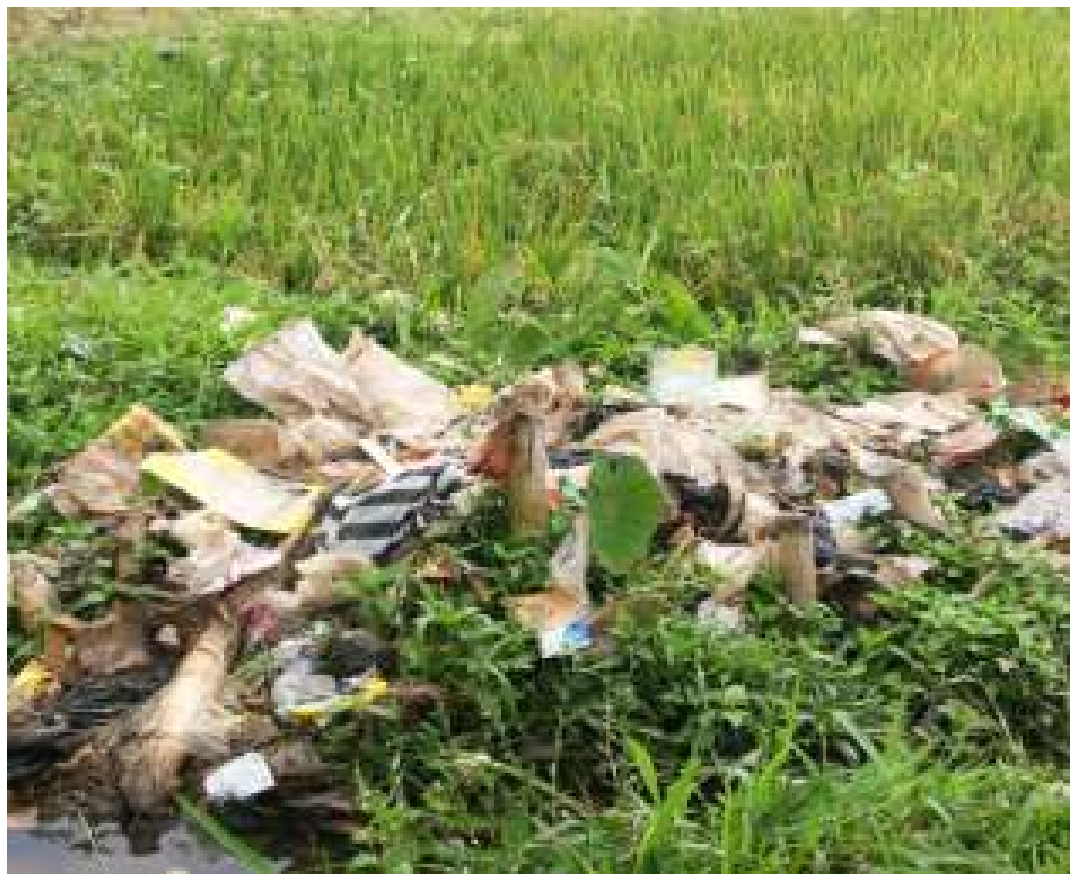

Gambar 3. Kondisi sawah yang dijadikan tempat pembuangan sampah

Disebabkan oleh kondisi di atas, hal tersebut mebuat masyarakat membuang sampah mereka ke sungai atau pun ke sawah yang dekat dengan pemukiman mereka, yang kemudian menjadi penyebab pencemaran pada sungai dan lingkungan persawahan. Di lain hal ada pula yang membakarnya di pinggir jalan yang menyebabkan bekas pembakaran tersebut berserakan 
di pinggir jalan dan mengakibatkan pencemaran udara serta mempengaruhi kelestarian desa akibat sisa pembakaran juga menyebar ke jalan. Masyarakat melakukan hal tersebut dengan alasan karena di pemukiman mereka belum terdapat TPS serta tidak adanya pengambilan sampah, atau dengan kata lain tiadanya sistem pengumpulan sampah di Desa Siluman.

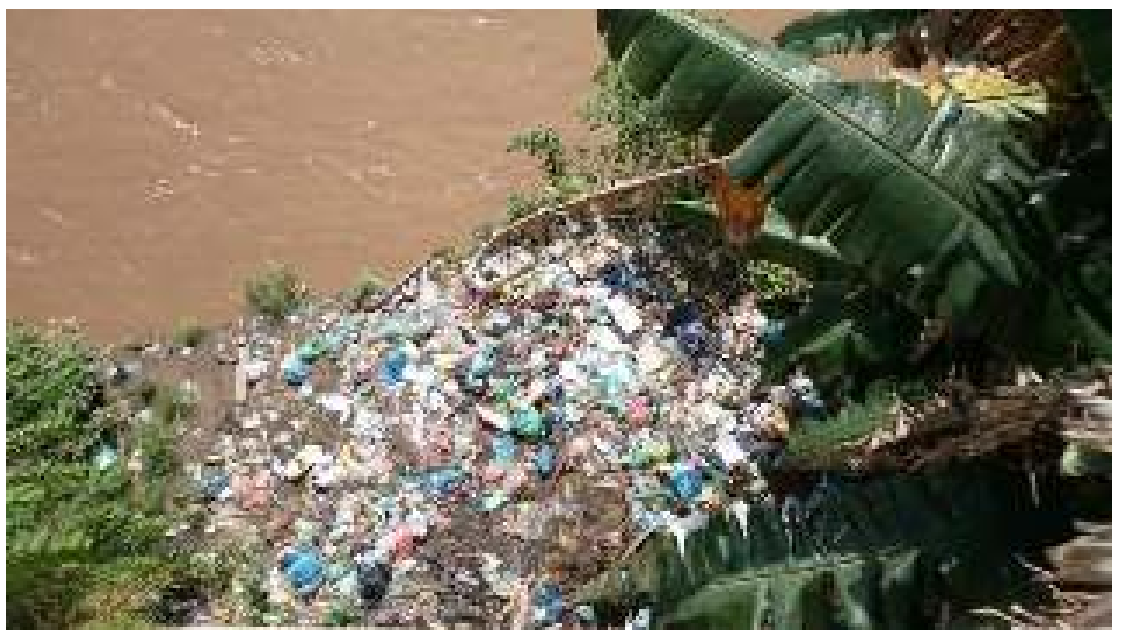

Gambar 4. Kondisi sungai yang dijadikan tempat pembuangan sampah

Berdasarkan kondisi di atas, menjadi hal yang begitu penting untuk menyusun solusi bagaimana caranya agar permasalahan sampah terutama yang disebabkan oleh sampah bermaterial plastik tersebut menjadi bisa dikurangi bahkan dikendalikan. Salah satu solusi yang bisa dilakukan adalah dengan membuat suatu projek yang bisa dilakukan bersama oleh masyarakat serta memiliki potensi untuk menghasilkan nilai tambah (value added) bagi mereka sehingga dapat meningkatkan antusiasme serta keterlibatan masyarakat dalam projek tersebut.

Adapun projek yang bisa dilakukan adalah dengan menggalakan pembuatan ecobricks atau bata ramah lingkungan yang diisi dengan sampah plastik hingga padat. Ecobrick dapat menjadi solusi akar rumput terhadap permasalahan lingkungan yang disebabkan oleh sampah plastik. Ecobrick dapat dijadikan upaya untuk memberdayakan individu untuk bertanggung jawab atas sampah mereka. Teknis pelaksanaan dari pembuatan Ecobrick dapat dilakukan dengan mudah, hal ini karena prsosesnya dapat dilakukan secara sederhana dan oleh kalangan mana pun. Selain itu hasil dari pembuatan Ecobricks ini dapat dimanfaatkan untuk membuat suatu karya seni instalasi, kerajinan tangan, ataupun dibuat sebagai bahan pembuatan meja, bangku, kursi, hingga untuk material pembangunan taman dan sebagainya. Atau dengan kata lain, dengan projek ini dapat memberi nilai tambah bagi masyarakat.

\section{METODE}


Sebelum kegiatan Pengabdian Masyarakat (Abdimas) ini dilaksanakan, team melakukan terlebih dulu persiapan yang menunjang kelancaran kegiatan Abdimas, seperti peninjauan/observasi lapangan untuk pelaksanaan kegiatan untuk menggali informasi dari masyarakat (dalam hal ini dilakukan melalui anggota Karang Taruna).

Secara umum, adapun bentuk kegiatan dari Abdimas ini adalah melalui pemaparan mengenai dampak penggunaan produk bermaterial plastik, cara mengurangi penggunaan plastik, serta alternatif solusi yang bisa dilakukan untuk mengurangi limbah plastik melalui pembuatan Ecobricks, yang selanjutnya dilanjutkan dengan pelaksanaan simulasi dan pelatihan pembuatan kreasi dari Ecobricks.

Teknis pelatihan yang dilakukan pada program pengabdian ini dilakukan melalui 3 tahapan sebagai berikut:

1. Pelaksanaan kegiatan pengabdian dilaksanakan di dalam aula Kantor Desa Siluman.

2. Pemaparan materi disampaikan oleh peneliti yang merupakan Dosen pengajar Program Studi Ilmu Pemerintahan Universitas Singaperbangsa Karawang.

3. Peserta pelatihan berpartisipasi secara aktif terkait dengan topik dengan dibukanya sesi tanya jawab

\section{HASIL DAN PEMBAHASAN}

\section{A. Pemetaan Sosial}

Siluman adalah salah satu desa di kecamatan Pabuaran, Subang, Jawa Barat, Indonesia. Sebagian besar penduduknya adalah bermata pencaharian sebagai petani. Adapun Home Industry yang berkembang di sana ialah sebagai meubeler. Kepala desa yang terpilih dari hasil pemilihan langsung tahun 2012 yang dilantik tanggal 11 Oktober 2012 ialah Bapak Warman yang merupakan putera daerah. Ia memiliki wawasan ke depan untuk dapat meningkatkan tingkat perekonomian masyarakat.

Langkah pertama yang dilaksanakan ialah melalui perbaikan infrastruktur terutama jalan. Dua tahun berjalan masa pemerintahannya, masyarakat telah merasakan perubahan yang signifikan di berbagai bidang. Pada bidang Sosial ia merupakan pioneer adanya bantuan dana kematian, pada bidang keagamaan di setiap tanggal 1 Muharram diadakan kegiatan Tabligh Akbar yang kemudian dijadikan sebagai agenda yang dilaksanakan secara rutin. Pada tanggal 06 Oktober desa Siluman mendapatkan penghargaan dari KEMENKUMHAM dan Gubernur Jawa Barat yang diserahkan oleh Bapak Bupati H. Ojang Sohandi sebagai salah satu dari 14 
Desa yang menjadi pemenang lomba Desa Sadar Hukum (SADARKUM).

Desa Siluman telah mengalami pemekaran beberapa kali dengan uraian yaitu: pada tahun 1982, Dusun Cilekor, Dusun Kadawung, Dusun Bakan Pintu dimekarkan menjadi sebuah Desa yang sekarang dengan nama Desa Kadawung. Maka setelah mengalami pemekaran Desa Siluman memiliki luas wilayah lebih kurang 716,928 Ha yang terdiri dari lima Dusun yaitu:

1. Dusun Siluman Kerajan

2. Dusun Siluman Girang

3. Dusun Siluman I

4. Dusun Siluman II

5. Dusun Bakan Subang

Berdasarkan kontur tanah, maka tinggi dari permukaan laut Desa Siluman adalah 29 Mdl, dengan jarak dari ibu kota kecamatan adalah sejauh $3 \mathrm{Km}$ dengan jarak tempuh sekitar 30 menit atau 1/2 Jam. Adapun jarak dari Desa Siluman ke Kota Kabupaten adalah sejauh $51 \mathrm{Km}$ atau bisa ditempuh selama $1 \frac{1}{2}$ Jam perjalanan.

\section{B. Analisis Hasil Lapangan dan Kegiatan Sosialisasi}

Berdasarkan social mapping yang telah dilakukan, maka diketahui bahwa disebabkan oleh jarak tempuh yang cukup jauh dari keberadaan TPS yang berada di kecamatan, serta ketiadaan sistem pengumpulan sampah yang secara terstruktur mengelola sampah-sampah penduduk untuk kemudian dikirim ke TPS, menyebabkan sampah-sampah tersebut menjadi tidak bisa dikelola dengan baik. Sehingga banyak mencemari sawah dan sungai, serta mencemari udara diakibatkan ada juga masyarakat yang membakar sampah-sampah mereka di tepi-tepi jalan.

Kondisi ini masih terus berlangsung hingga saat ini. Hal ini disebabkan pembangunan TPS baru akan dilaksanakan pada tahun 2020. Sehingga sampah sudah terlanjur menumpuk dan tidak dikelola dengan baik. Disebabkan hal tersebut solusi jitu untuk dapat mengurangi dampak dari penumpukan sampah harus segera dilakukan sebelum timbul masalah yang serius bagi ekosistem di Desa Siluman.

Dengan dilakukannya sosialisasi mengenai dampak sampah plastik bagi lingkungan yang dilanjutkan dengan simulasi pembuatan Ecobrick sebagai solusi jitu untuk mengurangi dampak dari keberadaan sampah plastik yang tak terkelola di lingungan, hal tersebut dipandang telah mampu dalam meningkatkan tingkat kesadaran serta partisipasi dari segala lapisan 
masyarakat di Desa Siluman. Hal tersebut dapat dilihat dari kehadiran yang secara antusias mengikuti proses sosialisasi dan tertarik untuk pembuatan produk dari Ecobrick.

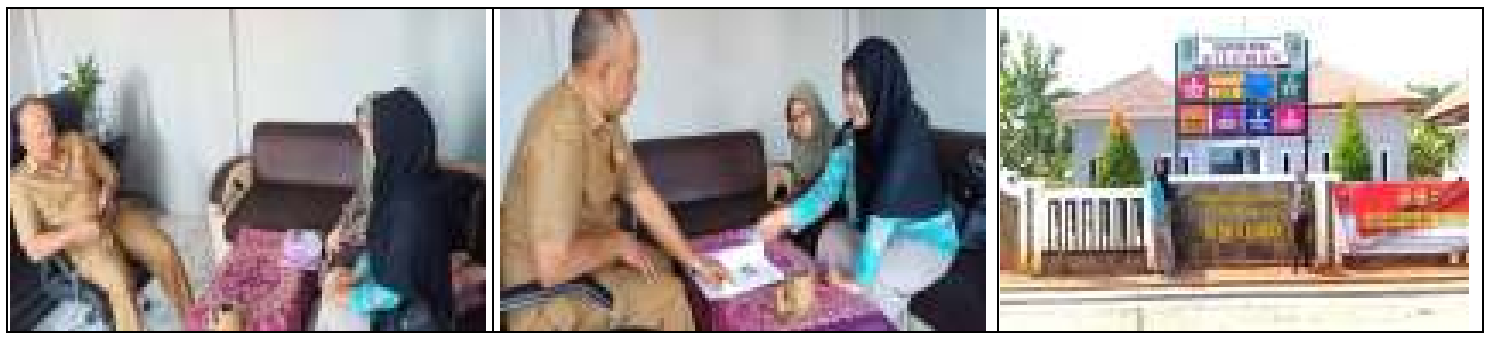

Gambar 5. Koordinasi Pelaksanaan Kegiatan Pengabdian kepada Masyarakat

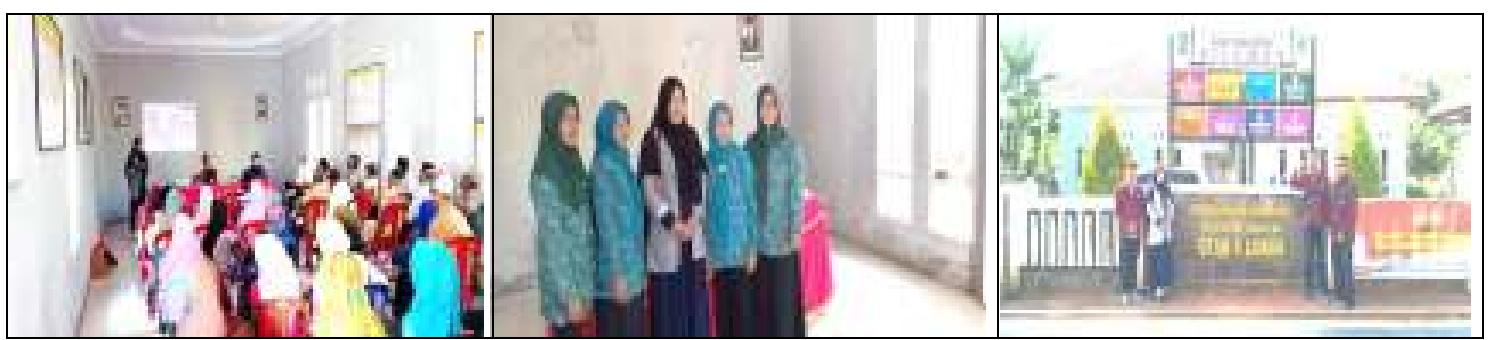

Gambar 6. Sosialisasi Pelaksanaan Kegiatan Pengabdian kepada Masyarakat

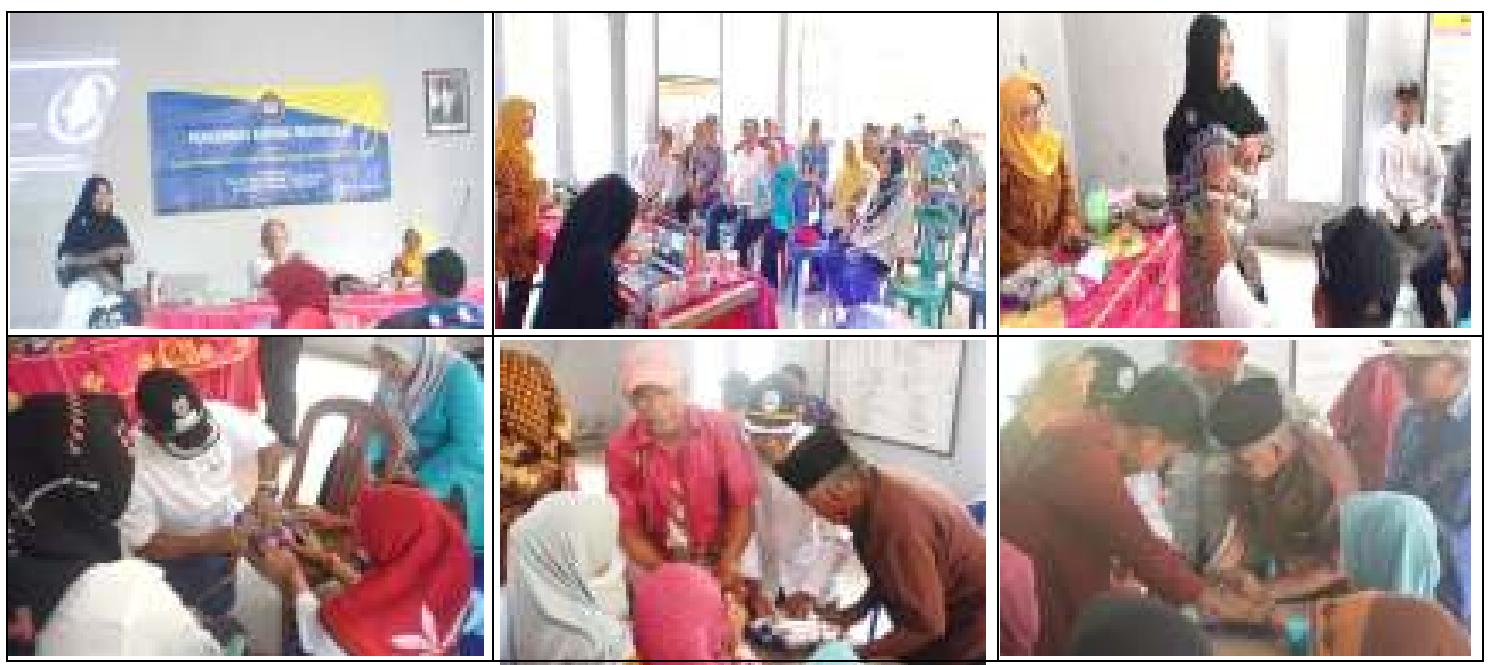

Gambar 7. Simulasi Pelaksanaan Kegiatan Pengabdian kepada Masyarakat

\section{SIMPULAN}

Kegiatan Pengabdian kepada masyarakat di Desa Siluman secara khusus difokuskan untuk dapat mengurangi dampak dari keberadaan sampah plastik yang berada di lingkungan Dwsa Siluman yang iudak terkelola sehingga berpotensi merusak lingkungan. Pengabdian ini pula berupaya untuk memberikan alternatif solusi melalui simulasi dan pembuatan produk dari hasil pembuatan ecobrick yang dilakukan oleh masyarakat Desa Siluman. Hal ini diupayakan sebagai wujud tanggungjawab sosial serta bagian dari Tridharma pula mendukung program Pemerintah di bidang lingkungan hidup yakni Program Citarum Harum.

\section{UCAPAN TERIMAKASIH}


Terimakasih tim PPM sampaikan kepada Rektor Universitas Singaperbangsa Karawang Prof. Dr. Wahyudin Zarkasyi, CPA atas skema riset Hibah Internal UNSIKA yang mendukung riset dan PPM yang dilaksanakan dalam semester genap 2019. Kepala Desa, Aparat, dan Masyarakat Desa Siluman Kabupaten Subang yang terlibat dalam kegiatan ini.

\section{DAFTAR PUSTAKA}

\section{Buku}

Hetifah, Sumarto, Sj. 2003. Inovasi, Partisipasi dan Good Governance. Jakarta : Yayasan Obor Indonesia.

Theresia, Aprillia. 2015. Pembangunan Berbasis Masyarakat. Bandung; Alfabeta

\section{Internet}

https://www.cnnindonesia.com/gaya-hidup/20180425101643-282-293362/riset-24-persensampah-di-indonesia-masih-tak-terkelola

\section{Jurnal Internasional}

Jambeck R, Jenna, etc. Plastic Waste Inputs from land into the Ocean https://www.iswa.org/fileadmin/user_upload/Calendar_2011_03_AMERICANA/Science2015-Jambeck-768-71____.pdf

https://zerowaste.id/waste/ecobricks/

https://www.ecobricks.org/pdfs/Dokumen\%20ToT\%20Ecobrick.pdf 